\title{
Nauczanie języka polskiego w polskiej kolonii w Brazylii - studium przypadku
}

\author{
Polish language teaching in Polish colony in Brazil \\ - case study
}

\author{
Alicja Goczyła Ferreira \\ Universidade Federal do Paraná \\ IORCID: 0000-0002-8986-0685
}

\begin{abstract}
The aim of this article is to present the results of research conducted in one of the Polish colonies in South Brazil. The object of the research were Polish language lessons taking place in this rural community. The methodological tools were: a questionnaire, answered by all the students, lessons observations and interviews with volunteers among the students and with the teacher. The article discusses the context and the conditions in which the lessons are held. It describes the students group, which is very diversified in terms of age and language competence. It was established that, depending on the definition applied, all the students or a part of them can be classified as heritage language learners (HLLs). The learners reasons for starting Polish classes and their objectives were also examined. Based on the observations and the interviews, it was concluded that the lessons are not adjusted to HLLs' needs, mainly due to the lack of access to specific teacher training and materials.
\end{abstract}

Key words: teaching of Polish as heritage language, Polish language in Brazil, Polish diaspora in Brazil

Streszczenie: Celem niniejszego artykułu jest przedstawienie wyników badań, których przedmiotem były zajęcia $\mathrm{z}$ języka polskiego odbywające się $\mathrm{w}$ jednej z polskich kolonii w Południowej Brazylii. Narzędziami metodologicznymi były: ankieta wypełniona przez wszystkich uczących się, obserwacje zajęć oraz rozmowy przeprowadzone z ochotnikami i z nauczycielką. W tekście omówiono kontekst i warunki, w jakich zajęcia się odbywają, oraz opisano grupę uczących się, bardzo zróżnicowaną pod względem wieku i poziomu kompetencji polonistycznych. Ustalono, iż zależnie od przyjętej definicji, wszyscy bądź część uczestników zajęć może zostać zaklasyfikowana jako uczący się języka polskiego jako odziedziczonego (UJOdz). Przeanalizowano również powody podjęcia nauki przez uczących się oraz jej cele. Na podstawie obserwacji oraz rozmów z uczestnikami wywnioskowano, że zajęcia nie są dostosowane do potrzeb UJOdz, czego głównym powodem jest brak dostępu do specjalistycznych szkoleń dla nauczycieli i odpowiednich materiałów dydaktycznych.

Słowa kluczowe: nauczanie języka polskiego jako odziedziczonego, język polski w Brazylii, polonia brazylijska 
Obecność języka polskiego w Brazylii sięga drugiej połowy XIX wieku, kiedy to rzesze Europejczyków, a wśród nich Polaków, przybiły do brzegów Brazylii z jednej strony zachęcane polityką imigracyjną tutejszych władz, a z drugiej - uciekające od trudnych warunków bytowych w swych rodzinnych stronach. W przypadku polskich przychodźców fala imigracyjna trwała, z różnym natężeniem, do wybuchu II wojny światowej, po której to znacznie osłabła, ograniczając się do stosunkowo niewielkiej grupy imigrantów politycznych. Szacuje się, że w latach 1884-1933 osiedliło się w Brazylii około 115 tysięcy osób polskiej narodowości (Kula 1981, 18). Choć stanowiły one jedynie około $3 \%$ wszystkich imigrantów przybyłych w tym okresie do Brazylii (IBGE 2000), należy zauważyć, iż stosunek ten przedstawiał się diametralnie różnie w regionie Południowej Brazylii, który stał się nowym domem dla ogromnej większości przybyszy z ziem polskich. W stanie Paraná, miejscu badania będącego tematem niniejszego tekstu, połowa imigrantów legitymowała się dokumentem potwierdzającym przynależność do polskiej narodowości (Martins 1941, 52-53, cyt. za Ianni 1987, 172).

W dzisiejszej Południowej Brazylii polska obecność jest już znacznie mniej widoczna, a w dużych miastach objawia się głównie w nazwach ulic i parków, fizjonomiach i nazwiskach mieszkańców, działalności tutejszych organizacji polonijnych oraz $\mathrm{w}$ niektórych tradycjach, takich jak święconka czy tańce ludowe. Polszczyzna ma swoje miejsce na Uniwersytecie Federalnym Parany, w stolicy stanu - Kurytybie, gdzie prowadzony jest kierunek polonistyka. Jednym z jego celów jest kształcenie nauczycieli języka polskiego, gdyż - pomimo egzotyki naszej mowy ojczystej dla dużej części brazylijskiego społeczeństwa - cieszy się ona stosunkowo dużym zainteresowaniem Brazylijczyków polskiego pochodzenia. W Kurytybie język polski rozbrzmiewa też w kilku szkołach publicznych na pozalekcyjnych zajęciach językowych, prowadzonych przez studentów wspomnianego kierunku w ramach programu Licenciar (zob. Piasecka-Till 2018) oraz podczas płatnych kursów językowych oferowanych przez Centrum Języków i Międzykulturowości przy Uniwersytecie Federalnym i przez Dom Kultury Polska-Brazylia. Można więc powiedzieć, iż w stolicy Parany język polski jest wykładany, ale stosunkowo rzadko funkcjonuje w życiu codziennym mieszkańców Kurytyby.

Jednak nawet krótka wyprawa w głąb kraju może okazać się miłym zaskoczeniem dla poszukiwaczy Polonii władającej polską mową. Liczne „polskie kolonie", czyli osady wiejskie założone niegdyś przez polskich imigrantów, a dziś zamieszkałe przez ich potomków, wciąż jeszcze są ostoją kultury i języka, przywiezionych do Brazylii 150 lat temu z drugiego końca świata. Wiele z tych społeczności przechodzi obecnie zaawansowany proces przesunięcia językowego, w którym język polski, po wielu dekadach sprawowania funkcji głównego kodu komunikacyjnego, odchodzi w zapomnienie na rzecz dominującego języka portugalskiego w jego brazylijskiej odmianie. 
Proces ten przebiega z różnym natężeniem w zależności od wielu czynników, takich jak chociażby oddalenie kolonii od większych skupisk miejskich. W niektórych miejscowościach polszczyzna jest nadal pierwszym językiem przyswajanym przez dzieci (Niewiadomski 2019), podczas gdy w innych przestała nim być około trzydziestu lat temu (Goczyła Ferreira 2019).

Zanikanie języka polskiego $\mathrm{w}$ koloniach połączone $\mathrm{z}$ wciąż silnym poczuciem polskości czy polonijności ich mieszkańców budzi w nich chęć (w niektórych przypadkach ponownego) nauczenia się języka swych przodków. Kontekst nauczania języka polskiego potomków polskich imigrantów w kolonii był tematem badania przeprowadzonego przez autorkę niniejszego tekstu w maju i w czerwcu 2019 roku w jednej z podkurytybskich miejscowości. Celem niniejszego artykułu jest przedstawienie głównych rezultatów tego badania opartego na hipotezie, iż grupa osób uczących się języka polskiego $\mathrm{w}$ wybranej kolonii nie jest jednolita pod względem kompetencji językowej ${ }^{1}$ i stosunku do języka polskiego. Biorąc pod uwagę ogromne zróżnicowanie wiekowe uczniów (od 12 do 70 lat), założono, że osoby nieznające języka polskiego uczą się go razem z tymi, którzy już się nim posługują, gdyż przyswoili go w dzieciństwie.

Celem badania była więc weryfikacja owej hipotezy oraz odpowiedź na następujące pytania badawcze:

1. Kto i w jakich warunkach uczy się języka polskiego w badanej kolonii?

2. Czy uczniowie mogą zostać zakwalifikowani do jednej z dwóch grup: uczących się języka polskiego jako obcego oraz uczących się języka polskiego jako odziedziczonego?

3. Czym różnią się oczekiwania i cele obu grup?

4. Jaki wpływ na przebieg i efektywność zajęć wywiera różnorodność grupy uczących się?

Aby uzyskać odpowiedź na postawione pytania, posłużono się trzema narzędziami metodologicznymi. Pierwszym z nich była ankieta składająca się z 13 pytań (zamkniętych i otwartych) dotyczących danych osobowych uczniów oraz ich motywacji, wrażeń i opinii na temat lekcji języka polskiego, wypełniona przez 40 osób. Drugim zastosowanym narzędziem były obserwacje zajęć w ciągu czterech godzin lekcyjnych. Niestety zbliżający się koniec roku szkolnego oraz choroba nauczycielki uniemożliwiły przeprowadzenie tej części badania w większym wymiarze godzin. Trzecią metodą gromadzenia danych były indywidualne wywiady przeprowadzone z nauczycielką oraz z sześciorgiem uczniów. Połączenie tych narzędzi umożliwiło przeprowadzenie analizy zebranych danych zarówno pod kątem ilościowym (dane $\mathrm{z}$ ankiety), jak i jakościowym (dane z wywiadów, obserwacji oraz otwartych pytań ankietowych).

\footnotetext{
${ }^{1}$ Termin kompetencja językowa jest rozumiany w niniejszym tekście jako kombinacja kompetencji gramatycznej (znajomości norm gramatycznych) i socjolingwistycznej (umiejętności niezbędnych dla komunikacji społecznej).
} 
W następnej części tekstu przejdziemy do analizy odpowiedzi na cztery pytania badawcze postawione powyżej, stanowiące punkt wyjścia dla przeprowadzonego badania.

\section{Kto i w jakich warunkach uczy się języka polskiego w kolonii?}

Niniejsze badanie zostało zrealizowane w jednej z podkurytybskich kolonii, której ogromną większość mieszkańców (około 80\%) stanowią potomkowie polskich imigrantów z końca XIX wieku. W celu zachowania anonimowości nauczycielki prowadzącej zajęcia nazwa tej niewielkiej, oddalonej o około $20 \mathrm{~km}$ od stolicy stanu miejscowości nie zostanie podana.

Zajęcia zjęzyka polskiego są tu od dawna wyczekiwaną nowością. Młodsi mieszkańcy wspominają krótki okres, około dziesięciu lat temu, kiedy oferowano tu lekcje polszczyzny, a starsi przywołują w pamięci lata 60. i 70. - czasy, w których księża z pobliskich parafii, przy okazji cotygodniowych wizyt duszpasterskich, udzielali dzieciom lekcji polskiego. Podobnie jak w większości polskich kolonii w Brazylii, również tutaj język polski pełnił rolę języka wykładowego w szkole podstawowej do połowy lat 30. ubiegłego wieku, kiedy to, wraz z innymi językami obcymi, był stopniowo usuwany ze szkolnictwa i ze sfery publicznej w wyniku nacjonalizującego ustawodawstwa ówczesnego rządu brazylijskiego (zob. Goczyła Ferreira 2018).

Zajęcia będące przedmiotem niniejszego badania rozpoczęto w marcu 2019 roku z inicjatywy samych mieszkańców, którzy po złożeniu wniosku do tutejszego konsulatu RP otrzymali dofinansowanie na materiały dydaktyczne. Pensja nauczycielki jest opłacana z niewielkich składek miesięcznych uiszczanych przez uczestników kursu. Początkowo miał on obejmować jedynie dzieci tańczące w polonijnym zespole folklorystycznym, jednak wobec ogromnego zainteresowania osób dorosłych zdecydowano się na włączenie do grupy wszystkich chętnych. Grupa, która początkowo liczyła około 50 osób, w momencie realizacji badania składała się z 41 uczniów w wieku od 12 do 70 lat, przy czym młodzież do 18. roku życia stanowiła niemal połowę (46\%) uczestników.

Jedynie dwie osoby w klasie nie są potomkami polskich imigrantów. W żyłach pozostałych 95\% uczestników płynie polska krew, a 76\% grupy stanowią osoby, których polskość pochodzi zarówno od strony matki, jak i ojca. Ta ostatnia informacja odzwierciedla wciąż jeszcze istniejącą w polskich koloniach ${ }^{2}$, choć słabnącą, tendencję do endogamii, czyli do zawierania małżeństw $\mathrm{z}$ osobami o tym samym pochodzeniu etnicznym.

Ankieta przeprowadzona wśród kursantów przed rozpoczęciem nauki na kursie zawierała pytanie dotyczące samooceny ich kompetencji polonistycznych w ramach czterech sprawności: mówienia, rozumienia ze słuchu, pisania i czytania. Uczestnicy mieli przyznać sobie ocenę od 1 do 4,

${ }^{2}$ Warto zauważyć, że tendencja ta nie odnosi się jedynie do kolonii polskich, ale również do społeczności zamieszkałych przez potomków imigrantów innych narodowości: niemieckiej, japońskiej czy ukraińskiej. 
przy czym 1 oznaczało, iż nie wykazują się daną umiejętnością, a 4 - że radzą sobie z nią bardzo dobrze. Biorąc pod uwagę fakt, iż wielu mieszkańców polskich kolonii traktuje swój dialekt polonijny jako ułomną odmianę polszczyzny standardowej (Wepik 2017, Goczyła Ferreira 2019), w pytaniu o kompetencję podkreślono, że chodzi o lokalną odmianę języka polskiego. Dla przykładu zdanie dotyczące rozumienia ze słuchu brzmiało (w tłumaczeniu na polski): „Kiedy ludzie z kolonii rozmawiają po polsku, rozumiem ich bardzo dobrze/dobrze/trochę/nic nie rozumiem".

Wykres 1. przedstawia średnie ocen każdej ze sprawności z podziałem na grupy wiekowe.

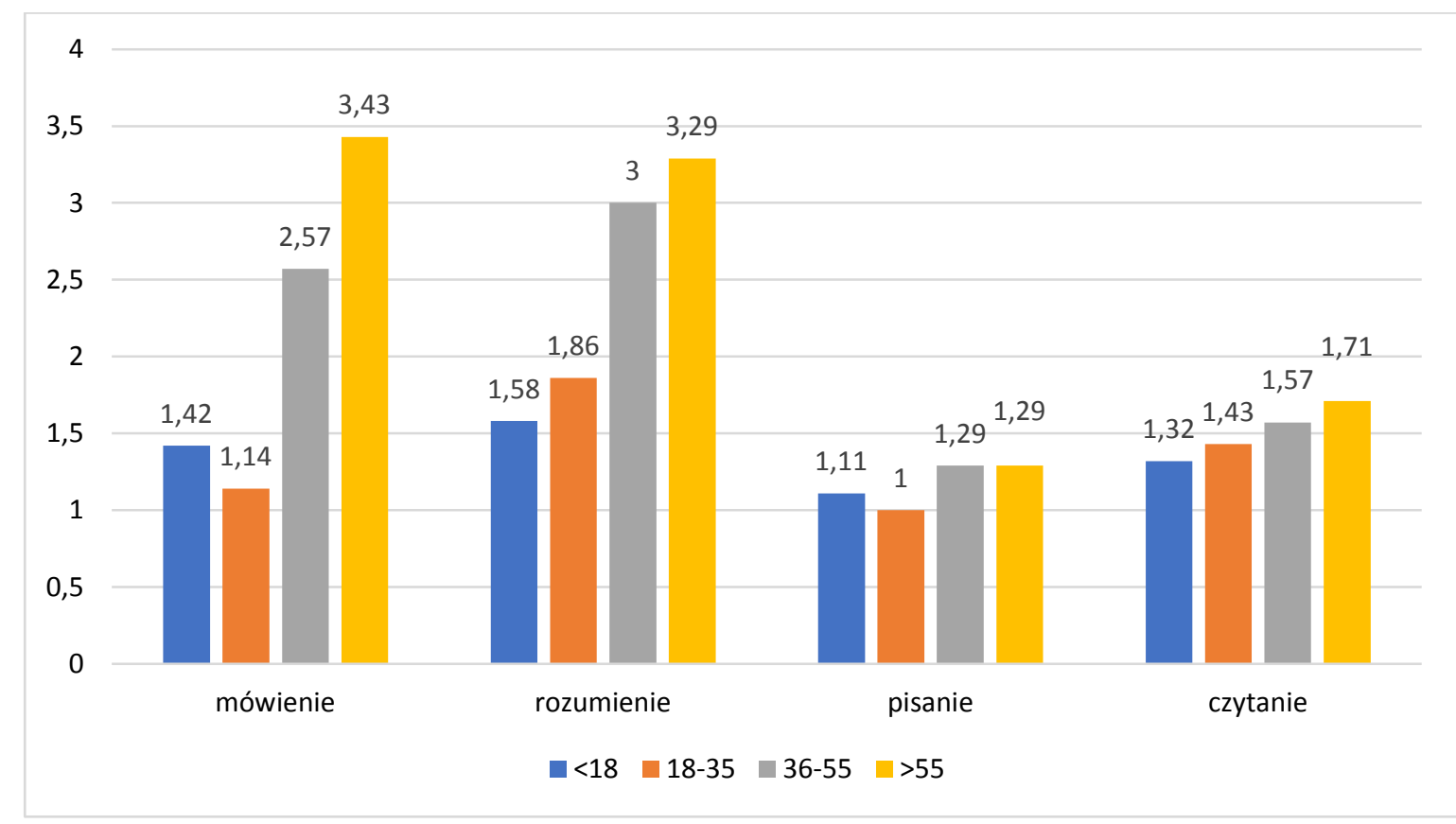

Wykres 1. Średnie samooceny sprawności w języku polskim uczniów z podziałem na grupy wiekowe (skala od 1 do 4; ocena 1 oznacza brak sprawności, 4 - bardzo dobre opanowanie sprawności)

Dwie tendencje zwracają uwagę przy analizie wyników samooceny. Pierwsza to wyraźna różnica między kompetencją młodszych i starszych uczestników zajęć, przy czym wiek 35 lat wydaje się wiekiem granicznym między grupą mniej i bardziej zaawansowaną. Fenomen ten jest rezultatem wspomnianego już procesu przesunięcia językowego, mającego swój początek w owej kolonii w połowie lat 70. i wciąż się nasilającego. Drugą zaobserwowaną tendencją jest dysproporcja poziomu sprawności związanych $\mathrm{z}$ językiem mówionym w porównaniu z językiem pisanym osób należących do dwóch najstarszych grup wiekowych. Ten wynik również nie jest zaskoczeniem, gdyż jest on konsekwencją prawie stuletniego okresu nieobecności języka polskiego w systemie szkolnictwa i jego zachowania jedynie $\mathrm{w}$ formie języka domowego. 
Prawdopodobnie największe wrażenie na nauczycielach języków czytających niniejszy tekst wywarła ogólna heterogeniczność grupy uczących się, zarówno pod względem wieku, jak i poziomu opanowania nauczanego języka. Przypomnijmy, że mamy tu do czynienia z 41-osobową, trzypokoleniową grupą uczniów, z których $30 \%$ uczy się polskiego praktycznie od zera, a $25 \%$ swobodnie posługuje się polszczyzną mówioną. Do różnorodności grupy uczących się należy jeszcze dodać niejednolitość dostępnych materiałów dydaktycznych. Z powodu nieporozumienia przy zakupie podręczników połowa grupy otrzymała podręcznik Hurra po polsku 1 (Małolepsza, Szymkiewicz 2010), a druga jej część - Polski, krok po kroku (Stempek i in. 2010). Osoba prowadząca zajęcia stanęła więc przed nie lada zadaniem, z którego - dodajmy - wywiązuje się, zdaniem ankietowanych, znakomicie. Należy jeszcze zauważyć, iż lekcje, odbywające się raz $\mathrm{w}$ tygodniu w późnych godzinach wieczornych, trwające po 120 minut, mają miejsce w sali parafialnej, dysponującej niewielką tablicą i raczej słabą akustyką.

Warto zwrócić uwagę na osobowość nauczycielki wychwalanej zarówno w ankietach, jak i podczas rozmów przeprowadzonych z uczniami. W odpowiedzi na otwarte pytanie „Co Ci się najbardziej podoba na kursie?” prawie $30 \%$ respondentów wymieniło „sposób, w jaki nauczycielka tłumaczy” bądź, bardziej ogólnie, jej podejście i zdolności dydaktyczne. Osoba prowadząca zajęcia, pochodzenia polskiego od strony jednego z rodziców, nie ma wykształcenia polonistycznego ani filologicznego, choć ukończone przez nią w Brazylii studia z innej dziedziny nauki obejmowały specjalizację nauczycielską. Po odbyciu studiów magisterskich w Polsce rozpoczęła pracę w firmie w Brazylii, a po paru latach zaczęła uczyć języka polskiego, co traktuje raczej hobbistycznie i robi to w celu zwiększenia swoich miesięcznych dochodów.

Nauczycielka uczęszcza na kursy metodyki nauczania języka polskiego oferowane corocznie przez tutejszy konsulat RP we współpracy z Uniwersytetem Federalnym Parany. Studia polonistyczne znajdują się w jej planach, choć przyznaje, że ich podjęcie nie będzie łatwe ze względu na czas, który musiałaby na nie poświęcić. Dodajmy, że zajęcia na polonistyce na uniwersytecie odbywają się w trybie wieczorowym, co z jednej strony umożliwia studiowanie osobom już pracującym, jednak z drugiej nie pozwala na łączenie studiów z nauczaniem języka polskiego, które z reguły toczy się o tej samej porze.

\section{Uczący się języka polskiego jako obcego czy jako odziedziczonego?}

Zaobserwowana sytuacja nauczania języka polskiego w badanej kolonii zobrazowała rozmaitość ról, jakie polska mowa odgrywa w życiu uczących się jej oraz wpływu owej różnorodności na motywację uczniów i na sam proces uczenia się. Wprawdzie dogłębna analiza tego problemu nie będzie 
możliwa w ramach niniejszego tekstu, jednakże bliższe spojrzenie na heterogeniczną strukturę grupy pozwoli na przynajmniej częściowe zrozumienie dynamiki i procesów zachodzących podczas kursu.

Przejdźmy zatem do kategoryzacji pojęć języka obcego i odziedziczonego, gdyż „tylko ich właściwe rozumienie umożliwia odpowiednie ukierunkowanie/nachylenie procesu nauczania" (Lipińska, Seretny 2013, 4). Dla celów niniejszej pracy przyjmujemy definicję języka obcego jako języka nieojczystego, którego „uczy się najczęściej w szkole lub na kursach, w warunkach sztucznych" (Lipińska 2003, 42). Język odziedziczony (heritage language) został zdefiniowany przez jednego ze swoich pierwszych teoretyków, Joshuę Fishmana, jako język o „szczególnym znaczeniu rodzinnym"3 dla użytkownika, używany w środowisku, w którym oficjalnym i dominującym systemem komunikacji jest inny kod (Fishman 2001, 81). W szerokim ujęciu terminem tym określa się języki nieoficjalne i nie większościowe. Posługują się nimi grupy określane jako tzw. mniejszości językowe, do których mogą należeć zarówno społeczności autochtoniczne, jak i napływowe (Valdés 2005).

Za użytkowników języka odziedziczonego uznaje się zwykle osoby dwujęzyczne, mające kontakt $\mathrm{z}$ językiem mniejszościowym od wczesnego dzieciństwa i posługujące się biegle językiem dominującym w danym społeczeństwie (Montrul 2012). Dwujęzyczność w tym przypadku jest często określana jako kontinuum kompetencji, niezależne od ich poziomu (Valdés 2014), co oznacza, iż za użytkownika języka odziedziczonego, zależnie od przyjętego stanowiska teoretycznego, może zostać uznana nawet osoba niewykazująca się żadnymi sprawnościami w owym języku (Wiley 2001).

Terminem niezwykle istotnym dla dalszych rozważań jest uczący się języka odziedziczonego (UJOdz) w odróżnieniu od terminu uczący się języka obcego (UJOb). Zdaniem Marii Carreiry (2004) głównym czynnikiem odróżniającym obie grupy uczniów są ich odmienne potrzeby językowe wynikające $\mathrm{z}$ różnic tożsamościowych oraz z faktu, iż UJOdz przynoszą $\mathrm{z}$ domu rodzinnego bagaż doświadczeń językowych i kulturowych związanych z nauczanym językiem. Dla Fishmana (2001) istotną kwestią przy nauczaniu języka nie jest biegłość językowa UJOdz, ale właśnie historyczna i osobista więź łącząca UJOdz z językiem przez nich odziedziczonym. Jednak opinia ta nie jest podzielana przez wszystkich badaczy z dziedziny nauczania języka odziedziczonego, z których duża część przywiązuje znaczną wagę do poziomu kompetencji uczących się oraz jej wpływu na proces i efekty nauczania.

Carreira (2004) analizuje istniejące definicje UJOdz i proponuje ich podział na trzy grupy, z których każda przyjmuje inne kryterium klasyfikacji uczniów jako UJOdz, co ilustruje tabela 1.

${ }^{3}$ „particular family relevance” 
Tabela 1. Definicje uczących się języka odziedziczonego zależnie od obranego kryterium klasyfikacji

\begin{tabular}{|l|l|}
\hline Obrane kryterium & Opis uczących się języka odziedziczonego \\
\hline $\begin{array}{l}\text { przynależność do spo- } \\
\text { łeczności }\end{array}$ & $\begin{array}{l}\text { członkowie społeczności, których korzenie językowe są } \\
\text { różne od dominujących w danym społeczeństwie }\end{array}$ \\
\hline pochodzenie & $\begin{array}{l}\text { osoby uczące się języka ze względu na swoje pochodzenie } \\
\text { rodzinne lub etniczne, jednak nienależące do społeczno- } \\
\text { ści związanej z językiem odziedziczonym }\end{array}$ \\
\hline kompetencja językowa & $\begin{array}{l}\text { osoby wykazujące się chociażby podstawowymi sprawno- } \\
\text { ściami w języku odziedziczonym, wyniesionymi z domu ro- } \\
\text { dzinnego }\end{array}$ \\
\hline
\end{tabular}

Źródło: opracowanie własne na podstawie Carreira (2004, 3-9).

Jeśli zastosujemy pierwszą grupę definicji, opartą na przynależności do społeczności o korzeniach językowych odmiennych od większości społeczeństwa, okaże się, że w zajęciach języka polskiego będących obiektem naszego badania biorą udział prawie wyłącznie osoby uczące się języka polskiego jako odziedziczonego. Tylko jeden uczeń pochodzi z innego miasta, podczas gdy wszyscy pozostali są mieszkańcami pobliskich polskich kolonii. Z drugiej strony kryterium pochodzenia etnicznego osób niebędących członkami społeczności (grupa 2) wskaże nam właśnie tę wspomnianą osobę jako uczącą się języka odziedziczonego.

Zupełnie inny obraz grupy jawi nam się po przyjęciu kryterium kompetencji, zgodnie z którym 65\% uczniów może zostać uznanych za UJOdz, gdyż 26 osób w grupie zadeklarowało, że jest w stanie zrozumieć, przynajmniej w niewielkim stopniu, rozmowę w lokalnej odmianie języka polskiego. W ujęciu Guadalupe Valdés (2014), która traktuje bilingwizm jako kontinuum kompetencji w dwóch językach bez względu na ich poziom, są oni więc dwujęzycznymi użytkownikami języka odziedziczonego.

Zaznaczmy, iż kompetencja językowa deklarowana przez uczestników kursu została wyniesiona z domu. Jedynie cztery osoby, wszystkie powyżej 55 roku życia, uczyły się już polszczyzny w sposób formalny, jednak - jak zaznaczyły - trwało to zaledwie kilka miesięcy. Wszystkie te osoby oceniły swoje sprawności w mówionym języku polskim na bardzo dobre. Należy więc wnioskować, iż podobnie jak w przypadku reszty grupy ich kompetencje zostały ukształtowane $\mathrm{w}$ wyniku kontaktu z językiem w środowisku domowym i społecznościowym. Język polski został przez nich zatem przyswojony, a nie wyuczony, zgodnie z terminologią stosowaną przez Lipińską i Seretny (2016).

Wśród ankietowanych znajdują się dwie osoby nieklasyfikujące się jako UJOdz według żadnej z cytowanych definicji, którym jednak nie można odmówić „dziedzicznej motywacji” (heritage motivation, Van Deusen-Scholl 2003). W żyłach tych osób nie płynie polska krew, jednak obie są częścią społeczności kolonii i obie uczą się jej języka, by móc pełniej uczestniczyć w jej życiu. Oto fragment wypowiedzi ustnej jednej z respondentek: 
Chcę się nauczyć. Dużo się wycierpiałam, bo nie znam języka. Żyję wśród Polaków i nie znam ich języka, nie? (...) Starsze osoby bardzo to sobie cenią. Chcą rozmawiać tylko po polsku. Skoro się jest wśród nich, trzeba znać [język]

Odpowiedź na pytanie postawione na początku tej części artykułu, czy mamy do czynienia z dwoma różnymi grupami uczniów: UJOb i UJOdz, zależy więc od przyjętej definicji UJOdz. Zgodnie z kryterium przynależności do społeczności połączonym z kryterium pochodzenia etnicznego prawie wszyscy uczestnicy kursu uczą się języka polskiego jako odziedziczonego. Z drugiej jednak strony kryterium kompetencji ujawnia wewnętrzne zróżnicowanie grupy wynikające z różnych stopni obecności języka polskiego w najbliższym otoczeniu uczących się. Zgodnie z tym kryterium dla około 35\% kursantów język polski jest językiem obcym.

\section{Czym różnią się oczekiwania i cele uczących się języka obcego oraz uczących się języka odziedziczonego?}

Dyskusja na temat statusu języka uczonego ma ogromny wpływ na proces jego nauczania. Jak zauważa Przemysław Gębal, dydaktyczne zakresy funkcjonowania języka polskiego jako obcego czy jako odziedziczonego są różne, a ich szczegółowe doprecyzowanie „wiąże się z realizacją innych celów dydaktycznych i prowadzeniem zajęć w odmiennych kontekstach edukacyjnych" (Gębal 2016, 62). W przypadku naszego badania stykamy się zjednym kontekstem nauczania, jednakże wewnętrzne zróżnicowanie grupy sugeruje, że obrane cele dydaktyczne mogą lub powinny być odmienne.

Zatrzymajmy się na chwilę nad cechami UJOb i UJOdz uznawanymi w literaturze tematu za istotne dla przebiegu procesu glottodydaktycznego. Odmienny sposób nabycia języka docelowego w przypadku obu grup jest niewątpliwie jedną z najbardziej brzemiennych w skutki różnic pomiędzy UJOb i UJOdz. Ci pierwsi poznają go z reguły w warunkach egzolingwalnych w ramach formalnej edukacji bądź na kursach językowych. Procesowi akwizycji nie towarzyszy tu zwykle kontakt z językiem docelowym w codziennej komunikacji. W przypadku UJOdz polszczyzna jest przyswajana w dzieciństwie, w warunkach naturalnych, w interakcji z członkami rodziny, co sprawia, że proces ten jest zbliżony do procesu przyswajania języka ojczystego (Lipińska, Seretny 2013).

\section{Motywacja}

Różnice w procesie nabywania języka sprawiają, że język odziedziczony staje się znacznikiem więzi grupowej oraz nośnikiem tożsamości grupy mniejszościowej (Lipińska, Seretny 2016). Przyjmuje zatem funkcje nieobecne w relacji użytkownika z językiem obcym. Bezpośrednią konsekwencją tych odmienności w stosunku do procesu glottodydaktycznego są

\footnotetext{
4 “Eu quero aprender. Já sofri bastante por não saber a língua. Estou no meio dos poloneses e não sei a língua deles, né (...). As pessoas de idade prezam muito polonês, só querem falar polonês. Se está no meio, tem que saber".
} 
wyraźne różnice w motywacji uczących się. Dla uczących się języka odziedziczonego jego nauka jest sposobem na poszukiwanie lub wzmocnienie swojej tożsamości i więzi z lokalną społecznością mniejszościową bądź z szeroko pojętą wspólnotą etniczną, do której może należeć również wspólnota „starej ojczyzny” (Van Deusen-Scholl 2003, Carreira 2004). Dlatego też, jak zauważa Kimberly Noels (2005), z socjopsychologicznej perspektywy nie należy ich klasyfikować jako uczących się języka obcego; ich orientacja wobec języka docelowego jest raczej instrumentalna.

Wracając do danych ankietowych uzyskanych podczas badania, przypomnijmy, że ponad $60 \%$ badanych miało kontakt z językiem polskim w domu lub w najbliższym otoczeniu, co zaowocowało mniejszym lub większym stopniem znajomości tego języka. Pozostali uczniowie nie przyswoili więc polszczyzny w dzieciństwie, co skłania do uznania ich za uczących się języka polskiego jako obcego.

Jeśli jednak przyjrzymy się motywacji uczniów z kolonii, ta klasyfikacja nie jest już tak oczywista. Jedno z pierwszych pytań zawartych w ankiecie brzmiało: „Dlaczego uczysz się języka polskiego?”. Analiza jakościowa odpowiedzi wykazała, że najczęściej podawanym powodem było utrzymanie kultury i korzeni polskich (13 odpowiedzi). Wychodząc z założenia, że odpowiedź ta będzie występować częściej u użytkowników języka polskiego jako odziedziczonego, przeanalizowano jej dystrybucję ze względu na zadeklarowaną kompetencję językową. Można było oczekiwać, że osoby o wyższej kompetencji w języku polskim będą przywiązywać większą wagę do jego wartości tożsamościowej, związanej z pochodzeniem etnicznym ankietowanych. Ta hipoteza nie potwierdziła się, co ilustruje wykres 2 .

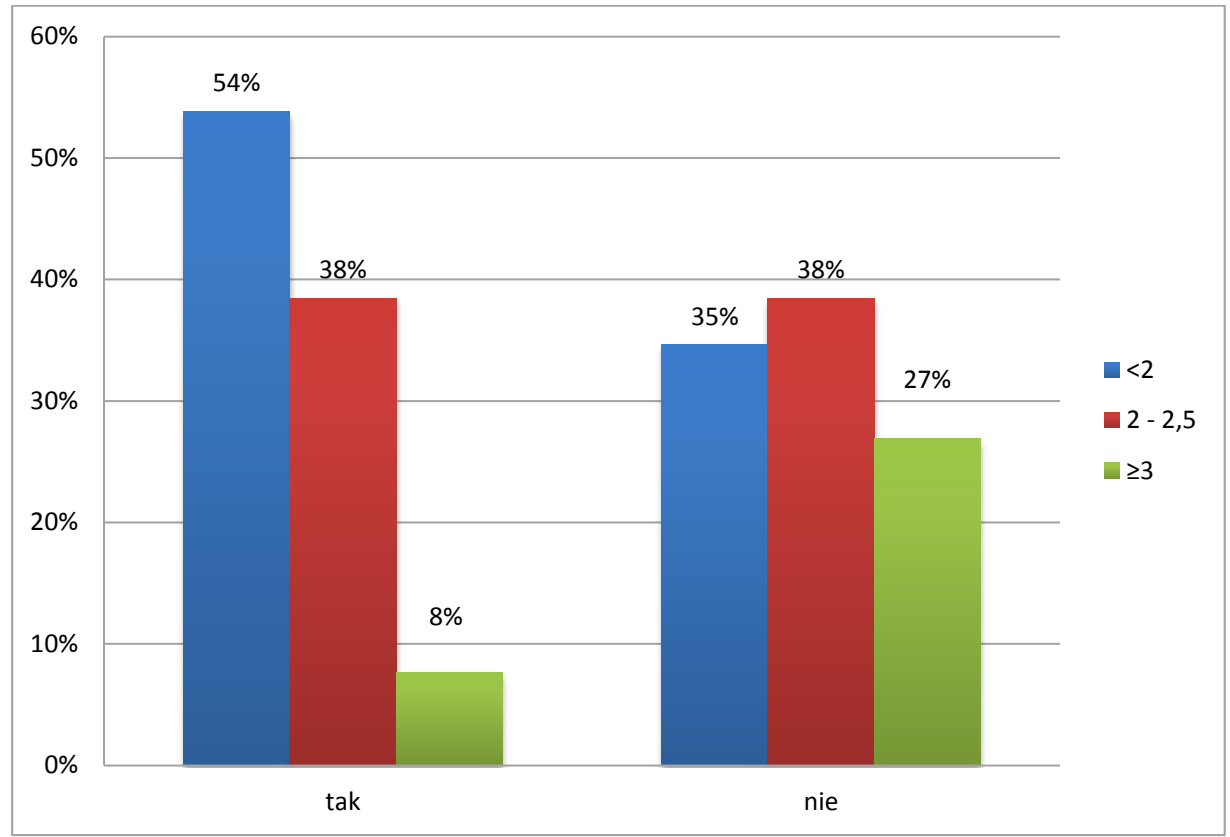

Wykres 2. Dystrybucja ankietowanych, którzy wymienili utrzymanie polskich korzeni jako powód uczenia się języka polskiego, ze względu na ich kompetencje $w$ języku polskim (średnia kompetencji $w$ j. mówionym) 
W badanej grupie wśród uczniów, dla których utrzymanie polskich korzeni jest główną motywacją do nauki języka polskiego, większość to osoby, które tego języka nie znają. Podobnie relacja ta przedstawia się, jeśli uwzględnimy wiek ankietowanych, gdyż - jak wspomniano powyżej - poziom znajomości języka jest tu dodatnio skorelowany z wiekiem uczących się. Osoby powyżej 55. roku życia uczęszczają na zajęcia przede wszystkim w celu nauczenia się pisania i czytania. Tylko jedna z nich wymieniła utrzymanie polskiej kultury jako powód podjęcia nauki języka. Można zatem wnioskować, że osoby posługujące się już językiem polskim w mniejszym lub w większym stopniu nie odczuwają silnej potrzeby zachowania swojej tożsamości, gdyż prawdopodobnie ta potrzeba jest już zaspokojona, przynajmniej w jakimś zakresie, właśnie przez znajomość języka przodków.

Owa tendencja do większego zwrotu osób młodszych bądź o niższej kompetencji językowej w stronę społeczności polonijnej i aspektów związanych z pochodzeniem etnicznym jest widoczna również przy analizie jednego z ostatnich pytań ankiety - zamkniętego pytania dotyczącego celów podjęcia nauki. Wykres 3. przedstawia odpowiedzi najczęściej wybierane przez badanych.

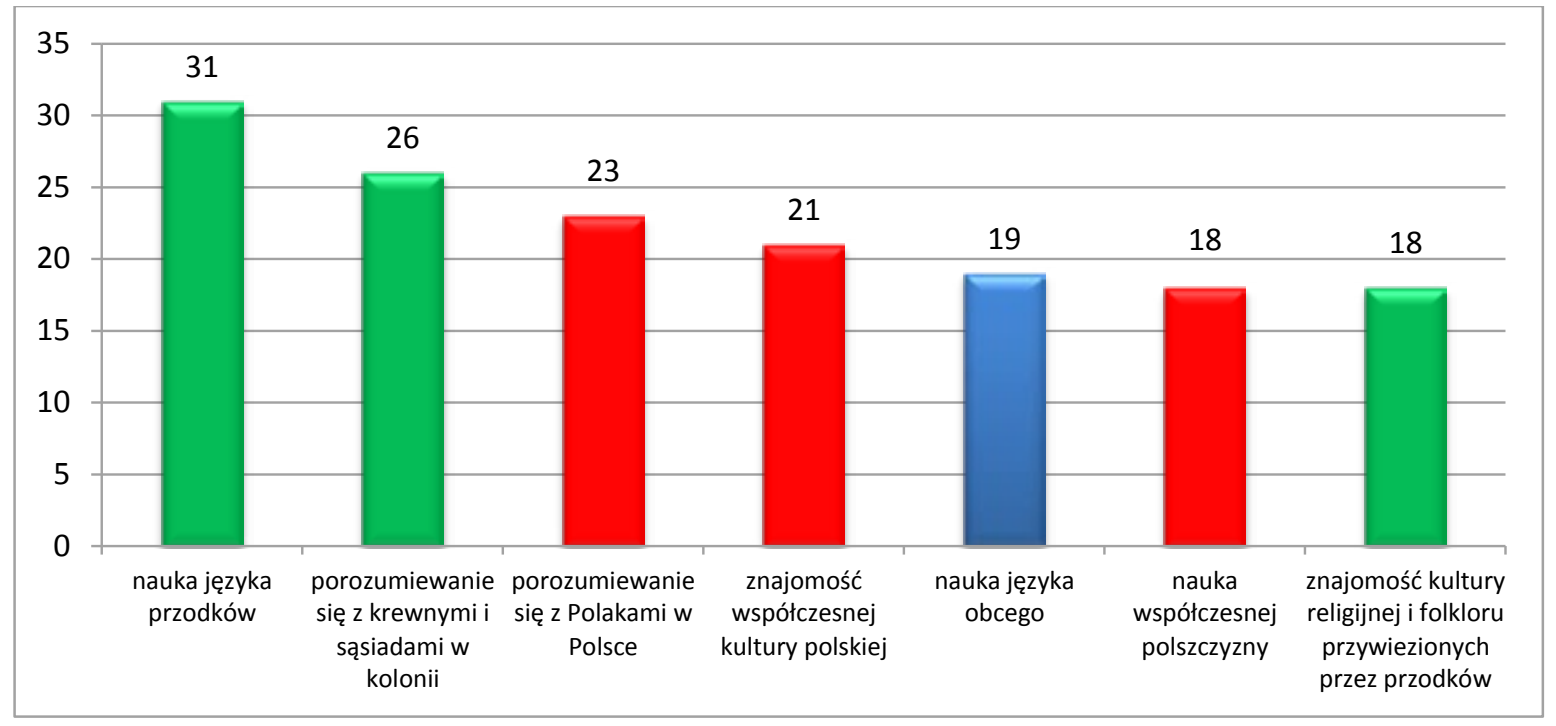

\section{Wykres 3. Cele uczenia się języka polskiego - liczba najczęstszych odpowiedzi na pytanie zamknięte wielokrotnego wyboru}

Zauważmy, że dwie najpopularniejsze odpowiedzi ujawniają skłonność do waloryzacji kultury lokalnej społeczności (kolor zielony). Przeplatają się one jednak z celami nauki zorientowanymi na współczesną Polskę i jej kulturę (kolor czerwony) czy też na „neutralną” naukę języka obcego (kolor niebieski). Niektóre z tych odpowiedzi wykazały zróżnicowanie dystrybucji przy uwzględnieniu wieku lub poziomu kompetencji ankietowanych. I tak, osoby starsze wykazują większe zainteresowanie nauką języka współczesnego niż języka przodków, podczas gdy w grupie osób pragnących poznać „mowę dziadów” prawie połowę stanowi młodzież. Poziom kompetencji 
wydaje się mieć umiarkowany wpływ na zainteresowanie kulturą współczesną bądź dawną, polonijną: osoby o mniejszej kompetencji językowej z reguły wykazują większy stopień zainteresowania kulturą polską przywiezioną do Brazylii przez przodków. Dane te zobrazowano na wykresie 4.
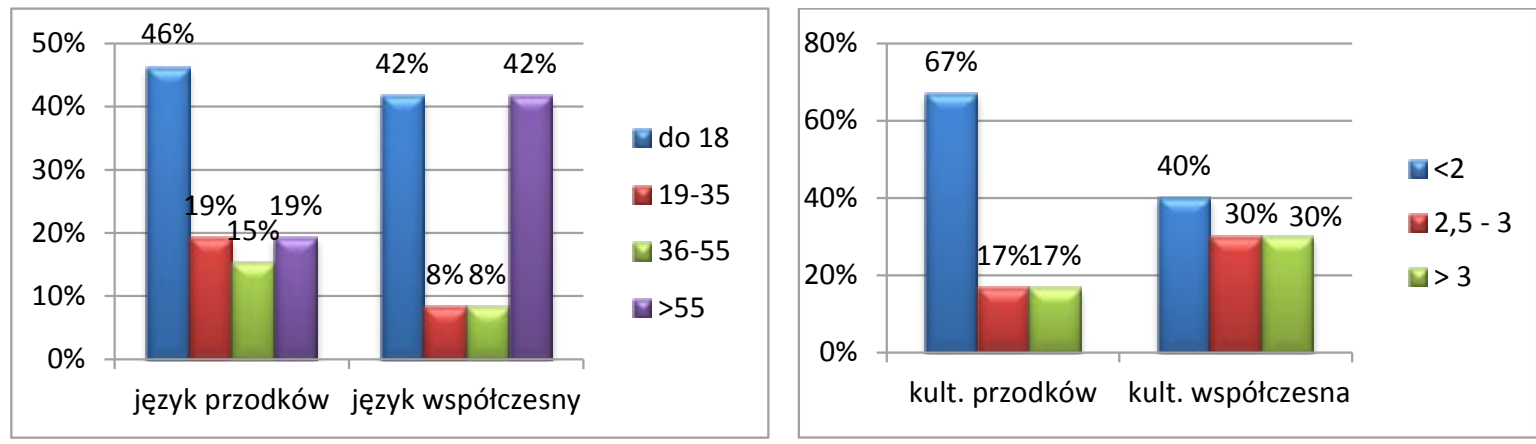

\section{Wykres 4. Wybrane cele podjęcia nauki języka polskiego ze względu na wiek (wykres z lewej) i poziom znajomości języka (wykres z prawej)}

Z dotychczasowych rozważań wynika, że stosując kryterium motywacji, uznanie osób niewładających polszczyzną za uczących się języka polskiego jako obcego wydaje się nie całkiem odpowiednie, gdyż dla $70 \% \mathrm{z}$ nich język ten jest znacznikiem więzi grupowej i nośnikiem tożsamości. Z drugiej strony różnica w kompetencji językowej, mająca ogromny wpływ na proces dydaktyczny, nie pozwala na zignorowanie heterogeniczności grupy. Dlatego dla celów niniejszego badania proponujemy użycie terminu uczący się języka odziedziczonego dla osób, które swoją znajomość języka wyniosły z domu, oraz terminu uczacy się z dziedziczna motywacją ${ }^{5}$ (Van Deusen-Scholl 2003) dla tych, którzy pomimo braku opanowania języka przodków postrzegają go jako część swego dziedzictwa i swej tożsamości.

\section{Znajomość języka}

Wspomniane powyżej różnice $\mathrm{w}$ procesie przyswajania lub nabywania języka docelowego rzutują również na stopień opanowania sprawności językowych oraz na przebieg ich uczenia się. Przypomnijmy, że proces przyswajania języka u użytkowników języka odziedziczonego zachodzi we wczesnym dzieciństwie w sposób zbliżony do przyswajania języka ojczystego. Jednak w momencie rozpoczęcia formalnej edukacji konfiguracja językowa, a z nią procesy akwizycji, u dwu - lub wielojęzycznego dziecka ulegają przekształceniom. Jeśli kontakt z językiem odziedziczonym ogranicza się jedynie do środowiska domowego, co często ma miejsce, słownictwo w danym języku również nie wychodzi poza zakres domeny życia codziennego i relacji międzyludzkich. Należy zaznaczyć, iż leksyka w ramach wspomnianego zakresu może być bardzo bogata, czego przykładem są UJOdz z badanej kolonii bez trudu odróżniający „kociołek” od „rondelka” czy „kosę” od „sierpa”.

\footnotetext{
5 „student with heritage motivation”
} 
Ekspozycja na język sprawia też, że pasywne sprawności receptywne UJOdz w języku mówionym znacznie przewyższają te sprawności u UJOb nawet na średnim poziomie zaawansowania (Noels 2005). Zdaniem Olgi Kagan i Kathleen Dillon (2012) sprawność rozumienia ze słuchu jest z reguły najbardziej rozwiniętą sprawnością u UJOdz, po której następuje sprawność mówienia. Z reguły poziom opanowania języka mówionego, w tym jego fonetyki, przez UJOdz jest wyższy niż u przeciętnych UJOb nawet po wielu latach nauki języka w środowisku formalnym (Kagan, Dillon 2012).

Kompetencja językowa UJOdz nie jest jednak tożsama $\mathrm{z}$ poziomem języka u jego przeciętnego użytkownika rodzimego. Lipińska i Seretny (2013) podkreślają brak znajomości standardowej odmiany języka, a szczególnie jego wersji pisanej. Język, którym posługują się UJOdz, wykazuje różnice gramatyczne $\mathrm{w}$ porównaniu z językiem rodzimych użytkowników w kraju pochodzenia. Jest też pozbawiony form oficjalnych, gdyż jego użytkownicy nie znają wszystkich rejestrów języka bądź też nie mają ich świadomości. Ze względu na swoją historię, mowa przekazywana z pokolenia na pokolenie z dala od macierzy do dziś zawiera elementy regionalne i archaiczne, często stygmatyzowane, czego przykładem może być mazurzenie u brazylijskich UJOdz.

Z rozmów przeprowadzonych z ochotnikami wynika, że dla osób znających już język polski największym wyzwaniem podczas zajęć jest opanowanie kodu pisanego, w szczególności samego pisania, co w następujący sposób przedstawia jeden z uczestników badania:

Teraz juz jest bardziej dobrze. Ale na początku.., Matko Święta. Ja nie wiedziałem, jak zacynać. Dzisiaj nie, dzisiaj jest bardzo tak niewiencij.

Z drugiej strony osoby, które wcześniej nie mówiły po polsku, zmagają się $\mathrm{z}$ wymową $\mathrm{w}$ tym języku, jak zauważa jedna $\mathrm{z}$ badanych:

AF: Co jest dla Pani najtrudniejsze?

B: Wymowa. Mój język się nie wykręca. Są takie słowa, których nie mogę wymówić. W niektórych trzeba mówić przez gardło, w innych przez nos. Nie nauczyliśmy się od małego, tych dźwięków, tych słów. Nie da się wymówić. (...) Jest więcej spółgłosek, mało samogłosek. A w brazylijskim same samogłoski ${ }^{6}$.

Z cytowanej wypowiedzi wynika, że badana porównuje swoje postępy w nauce z UJOdz, którzy nauczyli się dźwięków dla niej niewymawialnych jeszcze w dzieciństwie. Co ciekawe, problem z „wykręcaniem języka” (enrolar a língua) pojawia się w wypowiedzi innej badanej, dla której język polski jest językiem odziedziczonym. Porównując swoje doświadczenia z lekcji języka angielskiego i polskiego, kobieta przyznaje, że nauka tego ostatniego sprawia jej znacznie mniej trudności, gdyż w wymowie angielskiej konieczne jest owo „wykręcanie języka”, nieobecne, jej zdaniem, w języku polskim.

${ }^{6}$ AF: O que é mais difícil nas aulas? B: A pronúncia. A minha língua não enrola. Tem palavra que não consegue. Tem palavras que tem que sair pela garganta, outras pelo nariz. A gente não aprendeu desde pequeno, esse som, essas palavras. Não consegue falar. Tem mais consoantes, poucas vogais. Já o brasileiro, só vogal. 
Różnice w znajomości kodu mówionego wpływają oczywiście na sposoby radzenia sobie $\mathrm{z}$ kodem pisanym, co świetnie obrazują słowa jednego z badanych:

My [osoby mówiące po polsku] wiemy co są słowa, te dzieci młode nie znają, zacęły do zero (...). Jak ona [nauczycielka] tam powie co, to takie światło się rozświetli nad nami, wiemy co jest co robić (...). Mómy sposobu przecytać. A te dzieci, choćby przecytały i znają te litery, ale nie wiedzą, co słowo jest, co znacy to słowo.

Powyższe rozważania na temat różnic językowych między UJOdz i osobami niewładającymi jeszcze językiem docelowym wskazują, że grupy te znajdują się $\mathrm{w}$ zupełnie odmiennych momentach swoich procesów nabywania języka. Choć nie można powiedzieć, że ktokolwiek zaczyna uczyć się języka obcego od zera, gdyż zawsze wnosimy w proces nauczania nasze dotychczasowe doświadczenia językowe, nie ulega wątpliwości, że nasi UJOdz wykazują się znajomością kodu mówionego, gramatyki i potocznego słownictwa na poziomie znacznie odbiegającym od pozostałych uczestników grupy. Przyjrzyjmy się więc przebiegowi zajęć w tak różnorodnym gronie uczących się.

\section{Jaki wpływ na przebieg i efektywność zajęć wywiera różnorodność grupy uczących się?}

Opinia, iż UJOdz i UJOb powinni być nauczani oddzielnie, czy to ze względu na różnice językowe, czy też motywacyjne, jest dość powszechna wśród badaczy tematu (Carreira 2004, Valdés 2005, Kagan, Dillon 2012, Lipińska, Seretny, 2013). Zdaniem Kagan i Dillon (2012) UJOdz nie robią większych postępów w nauce na zajęciach dla początkujących UJOb, które skupiają się z reguły na wprowadzaniu już im znanego podstawowego słownictwa. Valdés (2005) przytacza przykład użytkowników języka hiszpańskiego jako odziedziczonego, uczących się tego języka w Stanach Zjednoczonych. Na zajęciach przygotowanych z myślą o UJOb mają oni problemy ze zrozumieniem pojęć gramatycznych dotyczących zagadnień przez nich już opanowanych w praktyce ${ }^{7}$. Poza tym nie są w stanie ograniczać swoich wypowiedzi podczas lekcji do niewielkiego zakresu leksyki zawartej w podręczniku, czego często oczekują od nich nauczyciele.

Kimi Kondo-Brown (2005) jest nieco odmiennego zdania, jeśli chodzi o oddzielne nauczanie UJOb i UJOdz, czego powodem jest dostrzegana przez badaczkę heterogeniczność ostatniej z tych grup. Twierdzi ona, że jedynie UJOdz o wysokim poziomie kompetencji językowej powinni być nauczani w odmienny sposób, albowiem ich proces uczenia się odbiega zarówno od procesu UJOb, jak i pozostałych UJOdz, których zgodnie z terminologią zawartą $\mathrm{w}$ niniejszym artykule nazwaliśmy UJOdz z dziedziczna motywacja. Autorka zaznacza jednakże, iż czynniki afektywne i tożsamościowe mogą mieć znaczny wpływ na nabywanie języka, co ewentualnie

\footnotetext{
7 Na przykład, różnica pomiędzy czasownikami „ser” i „estar”.
} 
uniemożliwiłoby wspólne nauczanie uczących się języka obcego i uczących się języka odziedziczonego o niskim poziomie kompetencji.

To właśnie czynniki tożsamościowe powinny być, zdaniem Carreiry (2004), wyznacznikiem treści programowych przy nauczaniu UJOdz. Badaczka proponuje, by na zajęciach językowych wykorzystywano ogromne zasoby wiedzy kulturowej uczniów należących do społeczności mniejszościowych oraz omawiano lokalne odmiany języka docelowego. Jeśli celem uczących się jest praca lub studia w kraju pochodzenia, należy skupić się na opanowaniu przez nich języka standardowego bądź też akademickiego.

W przypadku UJOdz o dziedzicznej motywacji praktyki pedagogiczne mogą ułatwiać uczącym się poszukiwanie własnej tożsamości w ramach odziedziczonego języka i kultury. Jako przykłady takich praktyk autorka proponuje „zbieranie przekazów ustnych krewnych [osoby uczącej się], spisanie swojej kulturowej autobiografii oraz badanie historii społeczności związanej z danym językiem odziedziczonym"8 (Carreira 2004, 8) w kraju osiedlenia uczącego się.

Gębal sugeruje, że rozwiązania metodyczne wypracowane w ramach obszaru nauczania języka polskiego jako obcego są na tyle uniwersalne i różnorodne, że umożliwiają „efektywny dydaktyczny transfer do nauczania języka polskiego jako (...) odziedziczonego" (Gębal 2016, 63). Carreira jest podobnego zdania, jednak tylko w przypadku UJOdz o niskim poziomie kompetencji językowej, dla których fuzja rozwiązań metodycznych typowych dla nauki języka obcego i odziedziczonego może okazać się korzystna. Autorka utrzymuje, że również ci uczniowie mogą coś wnieść do zajęć z języka obcego/odziedziczonego przez prezentacje słownictwa związanego z domem, liczb czy nazw własnych. Jeśli ich odpowiedzi różnią się od tych zawartych w podręczniku, mogą się one stać okazją do dyskusji na temat zróżnicowania i kontaktu językowego. Celem zachęcenia UJOdz o niewielkiej kompetencji językowej do aktywnego udziału w lekcjach jest uznanie ich odziedziczonej tożsamości i wyjątkowej relacji z językiem nauczanym (co często jest kwestionowane przez społeczeństwo ze względu na ich niski poziom językowy) oraz uświadomienie im, że są w posiadaniu wartościowej wiedzy o kulturze i języku swych przodków (Carreira 2004).

Lipińska i Seretny (2013) również podkreślają konieczność specyficznego ukierunkowania kształcenia językowego UJOdz, choć zauważają, że proces uczenia się/nauczania jest tu bliższy kształceniu językowemu cudzoziemców niż rodzimych użytkowników języka. Autorki proponują dostosowanie treści nauczania do potrzeb uczących się, co powinno opierać się w dużej mierze na „uzupełnianiu luk” językowych (s. 9). Celem takiego nauczania powinno być opanowanie standardowej wersji polszczyzny, osiągnięte m.in. przez rozwój leksyki abstrakcyjnej, naukę poprawnego zapisu i wymowy, nacisk na poprawność w rozwijaniu sprawności mówienia oraz

\footnotetext{
8 „compiling oral histories of relatives, writing heritage-culture autobiographies, and exploring the history of the HL community".
} 
rozwój sprawności pisania i czytania. Zdaniem badaczek, jeśli źródłem motywacji uczniów jest tożsamość, należy zaspokoić to zapotrzebowanie, zaznajamiając ich z polską kulturą wysoką. Trzeba podkreślić, że to stanowisko krakowskich autorek jest odmienne od zdania Carreiry (2004), dla której potrzeby tożsamościowe uczących się powinny być zaspokajane przez waloryzację ich kultury lokalnej, często bardzo różnej od kultury kraju pochodzenia i niedocenianej przez jego mieszkańców. Lipińska i Seretny (2013) nie negują jednak wagi kultury lokalnej, podkreślając konieczność osadzenia materiałów dydaktycznych używanych do nauczania UJOdz w lokalnych realiach, znacznie bliższych uczącym się od dalekiej im polskiej rzeczywistości.

Jak już wspomniano powyżej, podręczniki używane podczas zajęć w badanej społeczności nie są dostosowane do realiów uczących się 9 . Nauczycielka przyznała, że nie czuje się na siłach, by sama opracowywać materiały dydaktyczne, choć dokonuje selekcji treści, które jej zdaniem są przydatne kolonijnym uczniom. Uznała na przykład, że część podręcznika, w której uczy się formy „jestem z...” jest w kontekście kolonii mało użyteczna, gdyż wszyscy uczestnicy zajęć pochodzą z tego samego kraju.

Przypomnijmy, że choć grupa jest dość jednolita pod względem pochodzenia (95\% osób pochodzenia polskiego) i miejsca zamieszkania $(97,5 \%$ mieszka w pobliskich koloniach), należą do niej zarówno osoby nieposiadające żadnych sprawności w języku polskim (30\%), jak i te, które oceniły swój poziom znajomości języka mówionego na dobry bądź bardzo dobry (25\%). Pomimo tej różnorodności zajęcia są prowadzone w sposób dość tradycyjny, typowy dla początkowych stadiów nauczania języka polskiego jako obcego. Wprowadza się podręcznikowe słownictwo, do którego stopniowo dobudowuje się elementy gramatyki normatywnej standardowej polszczyzny. Osoba prowadząca stara się przedstawiać treści w sposób przystępny dla wszystkich uczestników zajęć, co oznacza, że wszystkie elementy pojawiające się $\mathrm{w}$ języku polskim są tłumaczone na język portugalski. Zapytana, jak sobie radzi z takim zróżnicowaniem poziomów w grupie, nauczycielka odpowiedziała:

Zawsze kieruję się poziomem tych, co wiedzą mniej. Niektórzy znają już wszystkie czasy, ale jeśli zrobię takie ćwiczenie, pozostałym będzie bardzo trudno. Zawsze na początku zajęć zadaję różne pytania. Tym, którzy wiedzą więcej, zadaję trudniejsze pytania, np. „Co robiłeś w sobotę”. Pozostałym - pytanie o to, co przerabialiśmy ${ }^{10}$.

Osoba prowadząca urozmaica zajęcia wieloma grami i ćwiczeniami o wysokim stopniu interaktywności, co bardzo sobie chwalą ankietowani. Stara się, by każdy z 41 uczniów wypowiedział choć jedno zdanie na głos

\footnotetext{
${ }^{9}$ Zarówno Hurra po polsku jak i Polski, krok po kroku są podręcznikami skierowanymi głównie do cudzoziemców uczących się języka polskiego w Polsce jako języka obcego.

${ }_{10}$ "Eu procuro sempre pelo que sabe menos. Tem gente que sabe falar em todos os tempos, mas se eu fizer atividade de ele não compreender, fica mais difícil. Sempre no início da aula faço rodada de perguntas. Àqueles que já sabem mais, eu dou uma pergunta mais dificil - "o que você fez no sabado". Os que sabem menos - o que a gente aprendeu na utlima aula".
} 
podczas zajęć. Poza tym uczący się mają wiele okazji do rozwijania sprawności mówienia w mniejszych grupach. Ćwiczenia rozwijające sprawność pisania są zadawane jako prace domowe i sprawdzane wspólnie na początku zajęć. Podczas naszej rozmowy nauczycielka wyraziła nadzieję, że dzięki nauczaniu od podstaw w pewnym momencie wszyscy uczniowie znajdą się na podobnym poziomie językowym. Choć nadzieja ta jest płonna (Carreira 2004), osoba prowadząca zajęcia nie szczędzi energii, by wszyscy uczestnicy mieli okazję do rozwijania swoich sprawności językowych.

Wydaje się, że podczas zajęć potencjał UJOdz o wysokiej kompetencji językowej nie jest wykorzystywany. Nauczycielka raczej ich nie zachęca do dzielenia się swoją wiedzą językową, choć niejednokrotnie jest konfrontowana $\mathrm{z}$ różnicami językowymi między językiem podręcznikowym a językiem kolonistów. W rozmowie z nami sama przyznała, iż stanowi to dla niej wyzwanie:

Mam z tym sporo trudności. Bo polski, którego się nauczyłam, jest inny od polskiego, w którym oni mówią. Głównie dlatego, że jest regionalny, to te dialekty. Mają inny akcent. Ja się nauczyłam „czarny”, a oni mówią „corny”. Ale ja im tego nie odbiorę, bo myślę, że to jest ich cecha charakterystyczna. Mówię im: to jest to samo, oznacza to samo. Nigdy nie powiedziałabym, że to jest niepoprawne, chociażby dlatego, że tak się mówi w kolonii ${ }^{11}$.

Podczas naszych rozmów uczniowie potwierdzili wrażliwość językową nauczycielki, którą dostrzegamy w jej wypowiedzi. Wytłumaczyła im ona, że podobnie jak język portugalski w Brazylii polszczyzna również jest zróżnicowana regionalnie ${ }^{12}$, co wielu z nich przekonało do „ważności” stosowanych przez nich form. Byli jej wdzięczni za akceptację ich sposobu wyrażania się, co nie zmniejszyło ich chęci do poznania „poprawnej” polszczyzny.

Nasza uwaga dotycząca braku zachęty wobec UJOdz do dzielenia się swoją wiedzą opiera się na obserwacjach zajęć, podczas których nauczycielka zdawała się nie wykorzystywać pojawiających się ku temu okazji. Przykładem takiej sytuacji może być moment, w którym uczący się zauważyli, że wyrażenia „przystojny” i „średniego wzrostu” są w kolonii nieznane. Naturalną reakcją byłoby tu prawdopodobnie pytanie nauczyciela, jakich wyrażeń używa się do opisu tych cech osób w lokalnym języku polonijnym, które jednak nie zostało zadane. Osoba prowadząca zignorowała uwagę uczniów, co można oczywiście tłumaczyć brakiem czasu, dużą liczbą uczniów utrudniającą dyskusję bądź obecnością obserwatora w klasie. Niemniej jednak ogólne wrażenie wyniesione z zajęć wskazuje, iż wzmacnianie poczucia tożsamości UJOdz czy omawianie lokalnych odmian języka

11 "Tenho bastante dificuldade. Porque o polonês que eu aprendi é diferente do polonês que eles falam. Principalmetne, porque é muito regional, aqueles dialetos. Eles tem um sotaque diferente. Eu aprendi 'czarny', eles falam 'corny'. Mas eu nunca vou tirar isso deles, porque eu acho que é a caracteristica. Eu digo: isso é mesma coisa, significa a mesma coisa. Nunca vou falar que isso é incorreto, até porque dentro da Colônia eles falam daquela maneira.".

${ }^{12} \mathrm{~W}$ mowie kolonistów obecne są nie tylko regionalizmy, lecz również dialektyzmy, archaizmy oraz cechy wynikłe z kontaktu z brazylijską odmianą portugalszczyzny. 
(zalecane m.in. przez Carreirę 2004 i Valdés 2005) nie są priorytetem podczas lekcji języka polskiego w kolonii.

Niewątpliwie zaspokojenie potrzeb językowych i kulturowych wszystkich uczniów jest praktycznie niemożliwe. Zarówno nauczycielka, jak i jeden z uczących się uznali, że zajęcia byłyby skuteczniejsze, gdyby podzielono uczniów na co najmniej dwie grupy - bardziej i mniej zaawansowanych. Następujące słowa jednego z UJOdz, wskazującego na różne cele nauki obu grup, potwierdzają tę tezę:

aby te młode się ucyli bardziej z pocątku, bardziej gramatycne. La nas bardziej, zeby rozmawiać, zeby pogodać, zeby sie nauczyć nowe słowa, zeby my się śmiali.

Tymczasem pozostali rozmówcy uznali właśnie wspomnianą heterogeniczność grupy za zaletę, co opisuje jeden z UJOdz:

Na początku myśleliśmy, że to się nie uda. Ale teraz owszem. Może to dobrze, że my wiemy troszkę więcej, ale młodzi, oni się od nas uczą. I to nam daje motywację, żeby nie zostać $\mathrm{w}$ tyle ${ }^{13}$.

Kursanci podkreślali również, jak bardzo cenią sobie możliwość wspólnej nauki w rodzinie, jako że w sali nie brakuje rodziców z dziećmi i dziadków z wnukami. Zaznaczali, że element towarzyski zajęć, jakże istotny, nie byłby obecny w takiej formie, gdyby rozdzielić uczących się na grupy. Ostatnim z wymienianych, choć równie ważnym argumentem była logistyka: rodzice i dziadkowie odwożący dzieci na lekcje nie muszą na nie czekać ani po nie wracać, a zaoszczędzony w ten sposób czas mogą spożytkować na własną naukę.

\section{Podsumowanie}

Celem niniejszego artykułu była analiza kontekstu i przebiegu zajęć z języka polskiego odbywających się $\mathrm{w}$ jednej z podkurytybskich kolonii polskich. Uczestnikami lekcji są prawie wyłącznie osoby polskiego pochodzenia zamieszkujące pobliskie kolonie, jednak grupa wykazuje znaczne zróżnicowanie pod względem wieku i stopnia opanowania języka polskiego. Zależnie od przyjętej definicji cała grupa bądź też jej bardziej zaawansowani językowo uczestnicy mogą zostać zaklasyfikowani jako uczący się języka odziedziczonego. Jednakże podczas obserwacji zajęć nie dostrzeżono zbyt wielu elementów dostosowania treści czy metodyki przeprowadzanych lekcji do tego specyficznego typu uczących się. Wnioskujemy, że fakt ten jest wynikiem heterogeniczności grupy i chęci dostosowania sposobu nauczania do osób najmniej zaawansowanych językowo. Jest to też prawdopodobnie spowodowane brakiem szkolenia metodycznego, które uświadomiłoby nauczycielce odmienne potrzeby językowe i kulturowe UJOdz oraz wskazałoby na praktyki pedagogiczne skuteczne w ich nauczaniu. Należy

\footnotetext{
13 „No começo a gente achava que não ia dar. Mas agora sim. Talvez é bom, se a gente sabe um pouquinho mais, os novos, nossa, eles aprendem com a gente. E a gente tambem se incentiva para não ficar atrás".
} 
podkreślić, iż sama nauczycielka nie ponosi winy za brak owego szkolenia, gdyż np. na kursie, prowadzonym m.in. przez autorkę tego artykułu, kwestie specyfiki uczenia języka polskiego jako odziedziczonego nie są praktycznie poruszane.

Pierwotne założenie, że rozdzielenie grupy na bardziej i mniej zaawansowanych wpłynęłoby pozytywnie na przebieg zajęć, zostało zakwestionowane przez samych uczących się, którzy cenią sobie możliwość nauki w wielopokoleniowej grupie, dającej im okazję do uczenia się od siebie nawzajem i dzielenia się swoją wiedzą.

\section{Bibliografia:}

A presença da língua polonesa na Colônia Dom Pedro II em Campo Largo, Paraná, 2019, praca magisterska, Universidade Federal do Paraná, Curitiba.

Carreira Maria, 2004, Seeking Explanatory Adequacy: A Dual Approach to Understanding the Term "Heritage Language Learner", Heritage Language Journal, 2.1.

Fishman Joshua A., 2001, 300-Plus Years of Heritage Language Education in the United States, w: Kreeft Peyton J., D. Ranard D.A., McGinnis S. (red.), Heritage Languages in America. Preserving a National Resource (81-99), McHenry, IL, s. 81-99.

Gębal Przemysław E., 2016, Nauczanie języka polskiego jako obcego, drugiego i odziedziczonego na tle rozwoju glottodydaktyki ogólnej i polonistycznej. Rozważania teoretyczne, Annales Universitatis Paedagogicae Cracoviensis.

Goczyła Ferreira Alicja, 2018, Polskość na antypodach: wybrane aspekty historyczne i językowe polskiej obecności w Brazylii, „Postscriptum Polonistyczne", 1 (21).

Ianni Octavio, 1987, Raças e classes sociais no Brasil, São Paulo.

IBGE, 2000, Brasil: 500 anos de povoamento. Rio de Janeiro, 2000. Apêndice: Estatísticas de povoamento. https://brasil500anos.ibge.gov.br/estatisticasdo-povoamento/imigracao-total-periodos-anuais (dostęp 15.11.2018)

Język odziedziczony - polszczyzna pokoleń polonijnych, 2016, Poradnik Językowy, 10.

Kagan Olga, Dillon Kathleen, 2012, Heritage languages and L2 learning, w: Gas S. M., Mackey A. (red.), The Routledge Handbook of Second Language Acquisition, London - New York, s. 491-505.

Kondo-Brown Kimi, 2005, Differences in Language Skills: Heritage Language Learner Subgroups and Foreign Language Learners, The Modern Language Journal, vol. 89, nr 4.

Kula Marcin, 1981, Polonia brazylijska, Warszawa.

Lipińska Ewa, 2003, Język ojczysty, język obcy, język drugi. Wstęp do badań dwujęzyczności, Kraków.

Lipińska Ewa, Seretny Anna, 2013, Nie swój lecz i nie obcy-język odziedziczony $w$ perspektywie glottodydaktycznej, w: Młoda polska emigracja w UE jako przedmiot badań psychologicznych, socjologicznych i kulturowych EuroEmigranci.PL, Kraków 23-24.IX.2013 r., www.euroemigranci.pl/dokumenty/ pokonferencyjna/Seretny_Lipinska.pdf (dostęp 15.12.2018)

Polonistyka. Innowacje

Numer 10, 2019 
Małolepsza Małgorzata, Szymkiewicz Aneta, 2010, Hurra po polsku 1, Kraków.

Montrul Silvina, 2012, Bilingualism and the Heritage Language Speaker, w: Bhatia T. K., Richie W. C. (red.). The Handbook of Bilingualism and Multilingualism. Wiley-Blackwell, s. 168 - 189.

Martins Romário, 1941, Quantos somos e quem somos, Curitiba.

Niewiadomski Sonia, 2019, Aspectos sonoros da língua polonesa falada em Cruz Machado no Paraná, praca magisterska, Unicentro, Guarapuava.

Noels Kimberly A., 2005, Orientations to Learning German: Heritage Language Learning and Motivational Substrates, The Canadian Modern Language Review, vol. 63, nr 2.

Piasecka-Till Aleksandra, 2018, Uczymy języka polskiego w Kurytybie: uniwersytecki projekt „Licenciar”, „Postscriptum Polonistyczne”, 1 (21).

Stempek Iwona, Stelmach Anna, Dawidek Sylwia, Szymkiewicz Aneta, 2010, Polski, krok po kroku, Kraków.

Valdés Guadalupe, 2005, Bilingualism, Heritage Language Learners, and SLA Research: Opportunities Lost or Seized?, Modern Language Journal, 89.

Van Deusen-Scholl Nellke, 2003, Toward a Definition of Heritage Language: Sociopolitical and Pedagogical Consideration, Journal of Language, Identity, and Education, 2 (3).

Wepik Fernanda F., 2017, Crenças e atitudes linguísticas de polono-brasileiros de Áurea/RS e Nova Erechim/SC: o uso dos termos de parentesco, praca magisterska, Universidade Federal da Fronteira Sul, Chapecó.

Wiley T.G., Peyton J.K. , Christian D., Moore S., Liu N. (red.), Handbook of Heritage, Community, and Native American Languages in the United States: Research, Policy, and Educational Practice. Routledge, London-New York, s. 27-35.

Wiley T.G, 2001, On Defining Heritage Language and Their Speakers, w: Kreeft J., Peyton D., Ranard A., Mcginnis S. (red.), Heritage Languages in America. Preserving a National Resource, McHenry, IL, s. 29-36.

\section{O Autorce:}

Alicja Goczyła Ferreira - od 2015 roku wykładowczyni języka i literatury polskiej w Katedrze Polonistyki Uniwersytetu Federalnego Parany w Kurytybie (Brazylia). W latach 2006-2014 była nauczycielką języka polskiego w Centrum Języków i Międzykulturowości przy tym uniwersytecie. Do kręgu jej zainteresowań naukowych należy obecność języka polskiego w Brazylii, jego historia i współczesność w kontekście kontaktu językowego oraz jego nauczanie. Obecnie prowadzi badania socjolingwistyczne w wiejskich społecznościach polonijnych w Południowej Brazylii. Jest autorką rozdziałów o Irenie Sendlerowej oraz Antoninie i Janie Żabińskich w zbiorze Memórias de Luz: Histórias de Poloneses Justos pod red. Piotra Kilanowskiego. 